\title{
ICT Utilization and Teaching - Learning in Business Education in Tertiary Institutions in Cross River State
}

Edet E. Okon

\author{
Francis I. Okon \\ Department of Vocational Education \\ University of Uyo, \\ Uyo-Nigeria
}

\section{Doi:10.5901/mjss.2013.v4n5p99}

\begin{abstract}
The study determined the relationship between ICT utilisation by Business Education Lecturers and Students and the teaching - learning of Business Education in tertiary institutions in Cross River State. The survey research design was adopted. The population comprises Business Education lecturers and Students totaling 985 on which 25 lecturers and 75 students were sampled for the study using stratified random sampling technique. Two sets of questionnaires were administered on the respondents after validation and reliability test. The reliability indices were 0.96 and 0.98 for ICTULSBEQ and TLBEQ respectively using Cronbach Alpha Reliability technique. The findings of the study show that ICT utilisation by lecturers and students has a significant positive relationship with teaching and learning of Business Education in tertiary institution. Based on the findings it is concluded that ICT utilisation if fully utilised will fill the skill gap among graduates of tertiary institutions. Based on the conclusion drawn it is recommended that tertiary institutions should equip their schools with ICT facilities while lecturers and students should make effort to own Personal Computers, internet enabled mobile phones among others, and equally utilize same for teaching and learning.
\end{abstract}

\section{Introduction}

Teaching and learning are transformational activities which involve two major variables - teacher and student. In the teaching-learning process emphasis is on students and on increasing their potentials to contribute to educational excellence. In addition to their conventional roles as recipients, students are the raw materials for education.

The grandiloquent role of students as recipients and raw materials for education becomes a paradox when teachers are not grounded with the knowledge, skills, techniques and other wherewithal needed to transform these students who are raw materials into useful outputs. Therefore, teachers are seen as catalysts. As catalysts teachers are expected to cause a change in the behaviour of these students. A teacher who can act as an ideal catalyst is an authority on the subject he/she teaches, flexible in attitude, exemplary in conduct, easily approachable, controls and directs when necessary and goes out of the way to allow leadership acts to emerge from learners.

Teaching itself is a two way communication but learning is more important than teaching because if teaching does not result in learning, it is futile. This implies that any teaching which does not result in a change in the bahaviour of learners is not teaching at all. Thus, prima facie terms like "need-based" teaching are used to describe the type of teaching that can put learners on achievement track. Any teaching plan should therefore be a symbiosis of theoretical vigour with "hand on" practical application.

This makes the utilisation of ICT by both lecturers and students in teaching and learning of Business Education in tertiary institution a serious episode. Federal republic of Nigeria (FRN, 2004) views tertiary 
education as the type of education given after secondary education in universities, colleges of education, polytechnics, monotechnics including those institutions offering correspondence courses. The goals of tertiary education is further highlighted by FRN to include contribution to national development through high level relevant manpower training; develop and inculcate proper values for the survival of the individual and society; acquisition of both physical and intellectual skills which will enable individuals to be self-reliant and useful members of the society, among others.

Unfortunately, graduates of Business Education in Tertiary Institutions having undergone reasonable period of teaching and learning processes come out of school without employable skills, thus, widening the unemployment that already at its chronic states in Nigeria.

The teaching and learning of Business Education requires the utilization of information and Communication Technology (ICT) for the inculcation of these skills especially to match pace with changes already experienced globally in the way both office work and business activities are carried out. The moment, the skill gap experienced among Business Education graduates in Nigerian tertiary institutions points to low utilisation of ICT.

\section{Statement of the problem}

Teaching and learning process in Business Education in Nigeria tertiary institutions is still at it crudest form. Both lecturers and students are still relying on textbooks information and lecturers class verbalisation due to the general poor attitude towards innovation. Both lecturers and students believe that government has neglected education. Consequently, it is observed that many Business Education lecturers and students are yet to fully utilise ICT for teaching and learning. Thus, calling for researches in this direction.

\section{Purpose of the Study}

This study determines the utilisation of ICT in teaching-learning Business Education in Nigeria tertiary institutions in Cross River State. Specifically, the study determines:

(1) The relationship which exist between ICT utilisation by Business Education lecturers and teaching of Business Education in Tertiary Institutions in Cross River State.

(2) The relationship which exist between ICT utilisation by Business Education students and learning in tertiary institutions in Cross River State.

\section{Research Questions}

1. What is the relationship between ICT utilisation by Business Education lecturers and teaching of Business Education in Tertiary Institutions in Cross River State?

2. What is the relationship between ICT utilisation by Business Education Students and learning of Business Education in Tertiary Institutions in Cross River State?

\section{Research Hypotheses}

(1) There is no significant relationship between ICT utilisation by Business Education Lecturers and teaching of Business Education in Tertiary Institutions in Cross River State.

(2) There is no significant relationship between ICT utilisation by Business Education Students learning of Business Education in Tertiary Institutions in Cross River State. 


\section{Review of Related Literature}

\section{Theoretical Framework of the Study}

This study is based on theory of student involvement propounded by Rosenshine 1982. This theory argues that for a particular curriculum to achieve the effects intended, it must illicit sufficient student effort and investment of energy to bring about the desired learning and development. The theory of student involvement provides a conceptual substitute for other theories such as the subject matter theory of pedagogy which emphasis that students' learning and development depend primarily on exposure to the right subject matter; the resource theory which maintains that if adequate resources are brought together in one place, student learning and development will occur.

All these theories tend to place students in passive role as recipient of information. On the contrary, the theory of students' involvement emphasizes active participation of the student in the learning process. The implication of this theory to this study is that with ICT utilisation in teaching-learning Business Education, both Business Educators (Lecturers) and Business Education students would participate in the process. However, students would be encouraged to learn more while the Business Educators focus less on what they do and more on what the students do.

\section{Conceptual Framework of Teaching and Learning}

Teaching and learning are inseparable concepts with learning playing more of judgmental role to teaching. It is believed that "unless the child learns the teacher has not taught". Though teaching and learning are intimately linked processes and are interdependent as well as inter woven, teaching is a social phenomenon, while learning is a psychological phenomenon. It is teaching which generally results into learning but there can be learning without teaching. Teachers in the recent trend of teaching and learning are therefore seen as facilitators or guide, and I believe this can better be enhanced through utilisation of ICT facilities.

The nub of teaching learning process lies in the moment by moment relationship between the willing leaner and the competent co-teacher. Rao (2008) quoted Burton (1958) who argues that teaching can be made effective by relating it to learning; teaching objectives can be identified in behavioural term and appropriate learning situations may be created to realise these objectives. The appropriate teaching condition or structures may be generated for effective learning; the effective teaching aids may be selected for creating strategies and tactics may be selected to achieve the optimal object of learning; the concept of relationship of teaching and learning will be an aid to understand the nature of teaching and thereby, teaching theories may be evolved. The knowledge of the relationship will equally be helpful for teaching to produce effective Business Education teachers.

\section{Business Education}

Business Education, an academic programme offered in tertiary institution is designed to provide learning situations for skill acquisition among students who could apply such skills in their occupation, managing personal business, for personal living in the society and for nation building. Its components are therefore a union of general education and business components. The growing need for business knowledge has continued to expand and increase from the era of industrial revolution in western world and indigenization policy (Osuala 2009). Business Education is increasingly demanded to fill the gap which unemployment has created. The skill gap of youths graduating from the nation's higher institutions must be filled otherwise the social vices and youth restiveness would hardly be averted.

There is therefore an unconditional need to get Business Education through a teaching learning process with optimum utilisation of ICTs. Only then that the programme could achieve its lofty goals. 


\section{ICTS}

ICT has been acknowledged globally as one of the greatest techniques infused into the teaching learning process. It is used in the context of this research work to imply a diverse set of electronic technologies, technological tools and resources used to communicate, disseminate, store and manage information in the course of teaching and learning.

ICT include computers, the internet, broadcasting technologies and telephony (Adoni and Kpangbam, 2010; Chukwudi and Ejita, 2008). The impact of ICT on learning is the vision that it enables learning anywhere, any time and anyhow. ICTs are utlised during academic activities especially by lecturers and students (Usang, Azubuike and Umoren, 2007). Anissimov (2009); Bless and Truth (2009) and Bliss (2009) agrees with this view but further noted that there is variation in the level of usage of ICT in tertiary institutions among countries.

A study conducted by Bassey, Umoren, Akuegwu, Udida and Ntukidem (2007) on Nigerian graduating students' access to e-learning technology revealed that very negligible number of graduating students have access to e-learnng technology. Also, Umoren and Bassey (2007) in a study on computer phobia and undergraduate students' performance in introduction to computer in South- south Nigeria found undergraduate students without computer phobia performing significantly higher than students with computer phobia.

\section{Methodology}

\section{Research Design}

The survey research design is adopted for the study. This design allowed the research the opportunity of generating data from lecturers and students through their objective opinion obtained through administration of questionnaire.

\section{Area of the Study}

The study was conducted in Cross River State of Nigeria. This state has potentials for business development in the areas of commerce, industry, tourism, agriculture, among others. Of course, Education generally and Business Education in particular is driving force that can ignite these sectors for productivity and national development.

\section{Population}

The population of the study comprises 150 Business Education lecturers and 835 students in four tertiary institutions offering Business Education in Cross River State. These institutions are:

1. Federal College of Education, Obudu

2. Cross River State College of Education, Akamkpa

3. Cross River State University of Science and Technology, Calabar

4. University of Calabar, Calabar.

\section{Sample and Sampling Technique}

A sample size of 100 comprising 25 Business Education Lecturers and 75 Business Education students drawn from two institutions was used for the study. The sample size was selected using stratified random sampling technique. 


\section{Instrumentation}

The researcher prepared two set of questionnaire for data generation. These are:

(1) ICT Utilisation by Lecturers and students of Business Education Questionnaire (ICTULSBEQ) in Tertiary Institution.

(2) Teaching-learning in Business Education Questionnaire TLBEQ in Tertiary Institutions.

\section{Validity of Instrument}

The instruments were validated by three experts. These comprises two Business Educators and the other in measurement and Evaluation.

\section{Reliability of the Instrument}

Cronbach Reliability method was used to test the reliability of the two instruments. This was achieved by selecting 30 respondents in each case who were not used for the main study. ICTULSBEQ and TLBEQ yielded reliability coefficients of .96 and .98 respectively and were seen to be reliable.

\section{Data collection Procedure}

The researcher administered the questionnaires personally on-the-spot. The administration yielded 100\% achievement.

\section{Data Analysis Technique}

Simple regression analysis was used to test the hypotheses at 0.05 level of significances.

\section{Analysis of Data}

\section{Research question 1}

What relationship exists between utilisation of ICT by lecturers and the teaching of Business Education in tertiary education in Cross River State? ICTULSTBEQ items 1-10 and TLBEQ, items 1-5 supplied data for answering this research question; summary data shown on Table 1

Table 1: Mean, Standard Deviation and Regression Coefficient for relationship between ICT utilisation by lecturers and teaching of Business Education.

\begin{tabular}{lcccc}
\hline Variable & $\mathbf{n}$ & $\overline{\boldsymbol{x}}$ & $\mathrm{SD}$ & $\mathrm{R}$ \\
\hline ICT utilisation by Lecturers & 25 & 21.05 & 6.36 & \\
& & & & 0.7435 \\
Teaching of Business Education & 75 & 98.23 & 7.23 & \\
\hline $\mathrm{N}=100$ & & & &
\end{tabular}

The value of $\mathrm{R}$ of 0.7435 in Table 1 indicates that the relationship between ICT Utilisation by lecturers and teaching of Business Education is positive and above average. 


\section{Research Question 2}

What relationship exists between ICT utilisation by students and learning of Business Education? ICTULSTBEQ items 11-20 and TLBEQ, items 6-10 supplied data for answering this research question; summary data shown on Table 2

Table 2:Mean, Standard Deviation and Regression Coefficient for relationship between ICT utilisation by lecturers and teaching of Business Education

\begin{tabular}{lcccc}
\hline Variable & $\mathbf{n}$ & $\overline{\boldsymbol{x}}$ & SD & $\mathrm{R}$ \\
\hline ICT utilisation by Students & 25 & 20.84 & 6.43 & \\
& & & & 0.5985 \\
Teaching/Learning of Business Education & 75 & 98.23 & 7.23 & \\
\hline $\mathrm{N}=100$ & & & &
\end{tabular}

The value of $\mathrm{R}$ of 0.5985 presented in Table 2 shows that ICT utilisation by Business Education students has average and positive relationship with learning.

\section{Research Hypotheses}

Null hypothesis One $\left(\mathrm{HO}_{1}\right)$

There is no significant relationship between ICT utilisation by lecturers and teaching-learning of Business Education. This hypothesis was tested using simple regression analysis. Summary data is presented on Table 3.

Table 3: Regression coefficient for relationship between ICT utilisation by lecturers and teaching - learning of Business Education.

$\begin{array}{llll}\text { Regression coefficient (R) } & = & 0.7435 \\ & \mathrm{R}^{2} & = & 0.5528 \\ & \mathrm{R}^{2} & = & 0.5376 \\ \text { Standard Error } & & = & 4.7336\end{array}$

\begin{tabular}{lccccc}
\hline Source of Variation & SS & df & ms & fcal & fcri \\
\hline Regression & 528 & 1 & 528 & & \\
& & & & $28.99^{*}$ & 6.96 \\
Residual & 5430 & 98 & 18.22 & & \\
Total & 5958 & 99 & & & \\
\hline $\mathrm{N}=100 \quad$ * significant $<.05$ & & & &
\end{tabular}

The result presented on Table 3 shows that the computed $F$ of 28.99 is greater than the critical $F$ of 6.96 at df of 1,98 and .05 level of significance hence the null hypothesis was rejected. Therefore, significant relationship exists between ICT Utilisation by lecturers and teaching learning of Business Education.

The value of $\mathrm{R}^{2}$ of 0.5376 indicates that ICT utilisation by Lecturers accounted for $53.76 \%$ of variation in the teaching and learning of Business Education. 


\section{Null hypothesis Two $\left(\mathrm{HO}_{2}\right)$}

There is no significant relationship between ICT utilisation by students and the teaching and learning of Business Education. Simple regression analysis was used to test this hypothesis and summary data is shown on Table 4.

Table 4: Regression coefficient for relationship between ICT utilisation by students and the teaching-learning of Business Education.

$\begin{array}{llll}\text { Regression coefficient }(\mathrm{R}) & = & 0.5985 \\ & \mathrm{R}^{2} & = & 0.3582 \\ & \mathrm{R}^{2} & = & 0.3375 \\ \text { Standard Error } & & = & 4.9537\end{array}$

\begin{tabular}{lccccc}
\hline Source of Variable & SS & df & ms & fcal & fcri \\
\hline Regression & 487 & 1 & 487 & & \\
& & & & 18.77 & 6.96 \\
Residual & 7730 & 98 & 25.94 & & \\
$\quad$ Total & 8217 & 99 & & & \\
$N=100 \quad$ * significant $<.05$ & & & &
\end{tabular}

Data presented on Table 4 shows that the computed $F$ of 18.77 is greater than the critical $F$ of 6.96 at df of 1,98 and 0.05 level of significance. Hence, the null hypothesis was rejected. This implies that there is significant relationship between ICT utilisation by students and teaching - learning of Business Education. The value of $\mathrm{R}^{2}$ of 0.3375 indicates that ICT utilization by Business Education students accounts for $33.75 \%$ of variation in teaching - learning of Business Education.

\section{Discussion of Findings}

The findings of this study are discussed in relation to literature earlier reviewed.

\section{ICT utilisation by lecturers and teaching - learning of Business Education:}

The finding shows that ICT utilisation by lecturers has a significantly positive relationship with teaching learning of Business Education in Tertiary institutions. Hence, this findings further confirms the views of Usang, et al (2007) who found in their study on ICT that ICT are utilised by lecturers during academic activities.

\section{ICT utilisation by students and teaching-learning of Business Education:}

The findings shows that ICT utilisation by students has a positive relationship with the teaching - learning of Business Education. Usang et al found out that students, like their lecturers utilise ICT during academic activities. Similarly, Umoren and Bassey (2007) reported that undergraduate students should not have phobia towards ICT based on the findings that students without phobia perform significantly higher than students with computer phobia. Also, Bassey et al (2007) found out that very negligible number of students in Nigeria higher institutions have access to ICTs. 


\section{Conclusions}

Based on the findings of this study, it is concluded that ICT utilisation for teaching - learning among Business Education lecturers and students will fill the skill gap experienced among Nigerian graduates. Also, it is concluded that ICT facilities facilitate effective teaching and learning process in Business Education.

\section{Recommendation}

Based on the conclusion drawn, it is recommended that ICT facilities should be made available by departments and institutions offering Business Education. Moreover, both lecturers and students should make efforts to own Personal Computer (PC), Internet enabled mobile phones and other facilities to augment gross inadequacies of ICTs in the school system.

\section{References}

Adomi, E. E. \& Kpangbam A. (2010). Application of ICTs in Nigerian Secondary Schools. Library Philosophy \& Practice (e-journal), March 1-8) http://digitalcommons.unl.edu/hsphipract/345.

Annissimov, M. (2009). What is Technology? http://www.wisegeek.com Accessed on 4/11/12

Bless, C. \& Smith C. (2009). Fundamentals of schools Research method: An African perspective. Lausdowue: Juta Education Ltd.

Belis, M. (2009). History of Computer, http://inventorsabout.com.Access 4/11/12.

Bassey, U. U., Umoren, G. U., Udida, L. A. \& Ntukidem, E. P. (2007) Nigerian Graduating students' Access to E-learning Technology: implications for Higher Education management. International Internet Education Conference \& Exhibition, Sept. 2-4, p.60.

Federal Republic of Nigeria (2004). National Policy on Education. Abuja: NERDC

Osuala, E. C. (2009). Business and Computer Education. Enugu: Cheston Agency Limited.

Rao, L. V. P. (2008). Teaching and Learning in Higher Education. In: George, D; Arasu, J. G. V; Agrawal, P. \& Gupta, M. K. Quality Education: Prospect and Challenges. New Delhi: A. P. H. Publishing Corporation.

Umoren, U.\& Bassey, U. (2007). Computer phobia and undergraduates students' performance introduction to computers in southern Universities in Nigeria. International Journal of Learning 14(2): 275. 